\title{
A UNIFIED GROWTH MODEL FOR INDEPENDENT CHILE*
}

\section{J. Rodrigo Fuentes*}

This article analyzes long-term patterns of growth of the Chilean economy. Examining 200 years of data, it shows evidence in favor of using a neoclassical growth model to conduct the empirical analysis. It presents a formal analysis of structural breaks in the Chilean growth process, finding structural changes in 1929 and 1971/1981. A further analysis of the country's economic history indicates that fiscal policy, external shocks and trade policy are plausible explanations for these breaks. When these variables are included in the empirical model, the hypothesis of no breaks during these 200 years cannot be rejected.

JEL classification: O11, N16

Keywords: Chile, structural breaks, growth, fiscal policies, external shocks

\section{INTRODUCTION}

In 2010, Chile celebrated 200 years of independence. After 200 years of economic history, Chile now faces a different challenge: how to become a developed country. This paper analyzes these 200 years from the perspective of long-term economic growth using formal statistical analysis. The goal of this research is twofold: First, to find a plausible theoretical model that is coherent with the data-generating process of the per-capita GDP and labor productivity series. Second, to examine the economic policies conducted over the 200 years to identify structural breaks in the series and common factors that underlie those breaks.

Many authors have divided Chile's economic history into sub-periods marked by certain historical (economic and political) events. This paper, in contrast, uses statistical techniques applied to an empirical model derived from theory in order to identify structural breaks and thus define different sub-periods that characterize Chilean economic history. Thus, the data divides Chilean economic history into different episodes. A deeper analysis of those periods allows for the identification of policies (in the case of Chile, trade and fiscal policies) that are the main forces driving economic results during those periods. Extending the empirical model to include proxies

\footnotetext{
* I would like to thank José Díaz, Rolf Lüders and Gert Wagner for helpful discussions and for providing me with data. Also, I want to thank Felipe Zurita and an anonymous referee for valuable comments. All the remaining errors are my own.

** Pontificia Universidad Católica de Chile. E-mail address: rodrigo.fuentes@uc.cl
} 
for these policies and a proxy of external shocks, we show that the evidence of structural breaks disappears.

The paper is developed in several steps. The first step consists of determining whether an exogenous or endogenous growth model is more suitable for explaining Chile's process of economic growth. The unit root hypothesis (data generated by an endogenous growth model) is rejected in favor of an alternative hypothesis that the per-capita and per-worker GDP series are trend stationary with breaks. Second, following this evidence, the paper develops a simple neoclassical growth model. Its analytical solution enables an empirical specification to be estimated for the entire period. The Bai-Perron test suggests two breaks in each series: 1929 and 1971 for per-capita GDP and 1929 and 1981 for per-worker GDP.

The third step is to identify those facts that could explain these breaks. The country's economic history sheds light on the reason for these structural changes. Although the Great Depression appears to be the obvious reason for the first break, according to the literature, policy changes were occurring at the same time that could also explain it. An important question, then, is why didn't the economy return to its original level after a temporary shock such as the Great Depression? In fact, the economy did recover from the Great Depression, but percapita GDP remained below the value predicted by the 1830-1930 trend. The hypothesis of this paper is that changes in the ways in which the government financed spending and the orientation toward trade are the main causes of this situation.

Regarding the second break, numerous reforms were implemented in the second half of the 1970s, directly contravening the increasing importance of the state in the economy that had occurred from 1940 to 1973. Again, reforms related to the role of the state and fiscal policy, in addition to the country's externally oriented development strategy, appear to be important reasons. Interestingly, by the end of this third period the economy was moving closer to its long-term trend. The question here is whether this recovery corresponds to a return to the trend or suggests that the economy was moving toward a different long-run equilibrium altogether. This question cannot be answered with the available data set, but deserves further study.

The last step consists of estimating an extended model that includes the ratio of government expenditures to GDP, average import tariff and terms to trade. According to this model, the hypothesis of no structural breaks during the 200 years of history cannot be rejected. 
The paper continues as follows: Section 2 analyzes whether the evidence in the Chilean data favors an endogenous or exogenous growth model. With the results obtained, Section 3 develops a simple model with an analytical solution that leads to a univariate representation of percapita and per-worker GDP. Section 4 presents the calculation and analysis of the structural breaks. Section 5 discusses plausible reasons for the breaks. In Section 6, an extended model is estimated to take into account the findings in Section 5, while concluding remarks are presented in Section 7.

\section{A FIRST LOOK AT THE DATA: ENDOGENOUS OR EXOGENOUS GROWTH}

A first step toward understanding the long-run evolution of the Chilean economy is to analyze the data-generating process behind per-capita GDP. Among the important implications of economic growth theory are the properties of the time series of per-capita income of an economy. The distinction between two classes of models - exogenous or endogenous growth - is based on whether transitory shocks, such as a temporary change in the investment rate, have a permanent effect on the level of per-capita GDP. Another way to test this is by checking whether permanent shocks, such as a permanent change in the investment rate, have an effect on the level or growth of per-capita income. This has been discussed at length in literature by Jones (1995), Lau (1997, 1999) and Kocherlakota and Yi (1997a,b).

Following Jones (1995), panel (a) in Figure 1 presents Chile's per-capita GDP from 1810 to 2009 and a deterministic trend line estimated for the entire sample. The trend seems to fit the data relatively well, with a slope of $1.52 \%$. However, a closer look reveals that the trend line underestimates per-capita output over the last 15 years and overestimates per-capita income from the post-Great Depression period until 1991. The Great Depression was an enormous shock to the economy, so the question is: If the economy were to grow at the same rate as it did before the Great Depression, where would it be today? The answer to this question can be found in panel (b) of Figure 1. A linear trend was estimated using data from 1830 to 1930 and extrapolated for the subsequent years. ${ }^{1}$ This figure shows that under the influence

1. Using data from 1810 to 1930 does not change the result. The study used data from 1830 , which is the year that many historians consider the Republic of Chile was established. 
of a significant, temporary shock such as the Great Depression, the economy suffered a drop in per-capita GDP which remained below the trend until 2008, when it reached the trend level once again. The long-term growth rate is $1.72 \%{ }^{2}$

Figure 1. Chile, per capita GDP and long-run trend

Panel (a): 1810-2009 trend

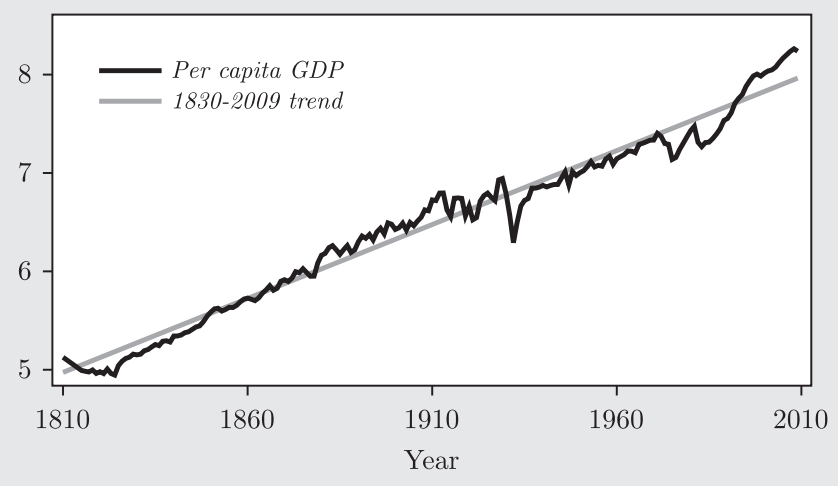

Panel (b): 1810-1930 trend

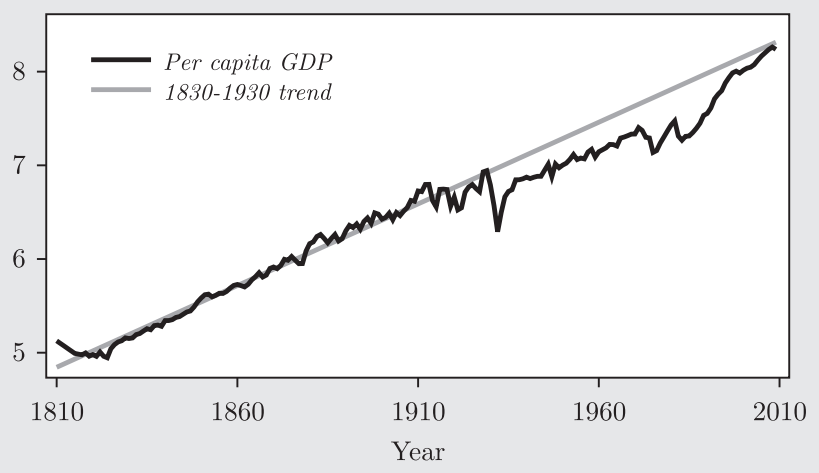

Source: GDP series from Díaz et al. (2003).

2. In a similar exercise, Jones (1995) found that a linear trend fitted for the U.S. GDP series, using the period 1880-1929, predicts quite well per-capita GDP in 1987.This is evidence that the growth trend did not change much, despite the Great Depression and the oil crisis of the 1970s. 
This evidence suggests the presence of a unit root in per-capita GDP, since a temporary shock had a permanent effect on the level of per-capita GDP. Alternatively, one could argue that the economy experienced a structural change which did not allow it to return to the level given by the long-term trend.

In summary, the casual evidence could be interpreted as an exogenous growth model with a structural change in the trend. But in panel (b) the evidence also seems to suggest that the data is generated by an endogenous growth model, with an important negative, temporary shock in 1930 and another positive, temporary shock in the mid-1980s. A more formal test of these models is presented in the following sections.

\subsection{Difference or trend stationary?}

The type of model used to explain the long-term performance of Chile's economy depends fundamentally on the data-generating process behind the per-capita GDP series. One of the attractive features of growth theory is that the implications of endogenous and exogenous growth models can easily be tested. Lau $(1997,1999)$ shows that a data-generating process for per-capita GDP that is consistent with endogenous growth models should be integrated of order 1. Unfortunately, the tests available are not powerful enough to completely discriminate between models; however, this is not a sufficiently strong argument not to proceed in applying them. Rejecting the null hypothesis of unit root lends support to the claim that an exogenous growth model could explain the evolution of per-capita GDP.

Chumacero and Fuentes (2006a) analyze the characteristics of the time series of per-capita GDP for 1810-1995 and find no evidence of unit root. This analysis is applied here using an additional 15 years of data. The traditional Augmented Dickey-Fuller test rejects the null of unit root (see Table 1). On the other hand, the Kwiatkowski, Phillips, Schmidt, and Shin (KPSS) test cannot reject the null that the series is trend stationary against the alternative of unit root. The Elliot Rothenberg and Stock (ERS) test is the only one that favors the null of unit root in the per-capita GDP series but not in the labor productivity series. More powerful tests such as the one developed by $\mathrm{Ng}$ and Perron (2001) also reject the unit root hypothesis. Zivot and Andrews (1992) develop a unit root test where the alternative joint hypothesis is that the series is stationary and there is a break 
in the level or the trend. The advantage of this test is that the break is endogenously determined by the data. As expected for such a long series, the null hypothesis of unit root is rejected.

The univariate analysis of the data tends to indicate that both per-capita and per-worker GDP are trend stationary. However, the evidence also points in the direction of a structural break in the series. The latter hypothesis is analyzed in the following section, using a more formal model.

\section{Table 1. Unit root tests}

\begin{tabular}{lccc}
\hline Test & \multicolumn{1}{c}{$\mathbf{H}_{\mathbf{0}}$} & GDP $/ \mathbf{P O P}$ & GDP $/ \mathbf{L}$ \\
\hline ADF & It has a unit root & NO* & NO* \\
KPSS & It is stationary & YES & YES \\
ERS & It has a unit root & YES & NO* \\
Ng and Perron & It has a unit root & YES & YES \\
ZA (level) & It has a unit root & NO*** & NO*** \\
ZA (trend) & It has a unit root & NO*** & NO*** \\
Note: No $=$ the null hypothesis is rejected at a significance level of $1\left({ }^{* *}\right), 5\left(^{* *}\right)$ or $10\left(^{*}\right)$ percent. \\
\hline
\end{tabular}

\section{A NEOCLASSICAL GROWTH MODEL}

In this section a simple version of the neoclassical model is examined. One of the main features of the model is the ability to generate trend stationary series of per-capita GDP. In order to have a closed-form solution, the model assumes preferences with a constant relative risk aversion equal to one and a Cobb-Douglas production function in a one-sector growth model. Consider a representative, infinitely lived household that maximizes

$$
U_{0}=\mathrm{E}_{0} \sum_{t=0}^{\infty} \beta^{t} L_{t} \ln c_{t}
$$

where $0<\beta<1$ is the subjective discount factor, $L_{t}$ is the size of the population (or labor force) at time $t, c_{t}=\left(C_{t} / L_{t}\right)$ is per-capita consumption in $t^{3}$ and $\mathrm{E}_{t}$ is the expectation operator depending on information available at period $t$. The household supplies inelastically

3. Lower-case letters denote per capita; upper-case total; and a tilde above a variable denotes per unit of effective labor. 
$L_{t}$ units of labor. Utility is maximized with respect to per-capita consumption, subject to the following budget constraint:

$$
K_{t+1}+C_{t}=e^{z_{t}} K_{t}^{\alpha}\left[(1+\gamma)^{t} L_{t}\right]^{1-\alpha}+(1-\delta) K_{t},
$$

where $K_{t}$ is the capital stock at time $t, \delta$ is the depreciation rate, and $\alpha$ is the compensation for capital as a share of GDP. In this economy, technological progress is labor-augmenting and occurs at the constant rate $\gamma$. Production is affected by a stationary productivity shock $z_{t}$. It is possible to rewrite the model in terms of effective unit of labor, $\tilde{k}_{t}=k_{t} /(1+\gamma)^{i}$ and $\tilde{c}_{t}=c_{t} /(1+\gamma)^{t}$ which makes $\tilde{k}_{t}$ and $\tilde{c}_{t}$ stationary. The solution of the stationary economy is the same as the above economy. This economy is characterized by the following problem:

$$
\max _{\left\{\tilde{k}_{t+1}, \tilde{c}_{t}\right\}} E_{0} \sum_{t=0}^{\infty} \beta^{t} L_{t} \ln (1+\gamma)^{t} \tilde{c}_{t}
$$

subject to

$$
(1+n)(1+\gamma) \tilde{k}_{t+1}+\tilde{c}_{t}=e_{t}^{z_{t}} \tilde{k}_{t}^{\alpha}+(1-\delta) \tilde{k}_{t}
$$

where $n$ is the rate of population growth, which is assumed constant. The stochastic process for the technology shock is given by:

$$
z_{t}=\rho z_{t-1}+\varepsilon_{t}, \quad \varepsilon_{\mathrm{t}} \sim \mathcal{N}\left(0, \sigma_{\varepsilon}^{2}\right)
$$

Assuming $\delta=1$, the analytical solution of this problem is the policy function for the capital per effective unit of labor expressed as:

$$
\ln \tilde{k}_{t+1}=\ln (\alpha \beta)-\ln (1+\gamma)-\ln (1+n)+\ln \tilde{y}_{t}
$$

where $\tilde{y}_{t}=e_{t}^{z_{t}} \tilde{k}_{t}^{\alpha}$ is the GDP per unit of effective labor.

Given that $\ln \tilde{y}_{t}$ can be expressed as:

$$
\ln \tilde{y}_{t}=z_{t}+\alpha \ln \tilde{k}_{t}
$$


we can replace (3) and (4) in (5) to obtain:

$$
\ln \tilde{y}_{t}=A+(\alpha+\rho) \ln \tilde{y}_{t-1}-\alpha \rho \ln \tilde{y}_{t-2}+\varepsilon_{t}
$$

where $A=\alpha(1-\rho)[\ln (\alpha \beta)-\ln (1+\lambda)]$. Recalling that $\tilde{y}_{t}(1+\lambda)^{t}=y_{t}$ we can use (6) to obtain a compact representation of the data-generating process of per capita GDP:

$$
\ln y_{t}=\phi_{0}+\phi_{1} t+(\alpha+\rho) \ln y_{t-1}-\alpha \rho \ln y_{t-2}+\varepsilon_{t}
$$

where $\phi_{0} \equiv A, \phi_{1} \equiv \ln (1+\gamma), \phi_{2} \equiv \alpha+\rho$, and $\phi_{3} \equiv-\alpha \rho$. Equation (7) is consistent with a series of per-capita GDP that is trend stationary as found in the data. Moreover, it shows that per-capita GDP follows an $\operatorname{AR}(2)$ process if the technology shock follows an $\operatorname{AR}(1)$ process. This equation includes as a special case the traditional AK model $(\alpha=1)$ and the unit root in the technology process $(\rho=1)$, but it is impossible to identify the value of any of these parameters.

\section{SEARCHING FOR BREAKS IN THE UNIVARIATE REPRESENTATION}

This section is divided into two parts. First, following the guidelines of the neoclassical growth model developed in the previous section, a univariate representation for GDP is estimated. Second, structural break tests are applied to the model to check for eventual nonlinearities or omitted variable problems. The analysis of the structural changes based on Chile's economic history is provided in the next section.

Table 2 exhibits the least-squares estimation of (7). The model in the previous section is parsimonious and therefore it is valid to ask whether an $\mathrm{AR}(2)$ process for per-capita GDP is enough to obtain parameters with the desired properties. However, the results show that two lags of the dependent variable are sufficient to obtain white noise residuals. But there is evidence of auto-regressive conditional heteroscedasticity, and of the residuals not being distributed normally. This may suggest that other variables are missing from the analysis. The long-term trend in the growth rate is given by $\phi_{1} /\left(1-\phi_{2}-\phi_{3}\right)$, which is equal to 1.6 percent, corresponding to the average growth rate of per-capita GDP over the entire period. The coefficients estimated are very similar for both equations, regardless of whether the dependent variable is per- 
capita GDP or per-worker GDP. Also, the sample is different for each equation, since there are no data on per-worker GDP before 1833 .

It is difficult to believe that a stylized model such as the one presented here could explain the long-term growth process over 200 years without evidence of structural changes. Moreover, the Zivot and Andrews test presented in the previous section rejects the null hypothesis of unit root in favor of stationarity in the series of per-capita GDP with a break. Numerous events could lead to structural changes at different moments in time; therefore, it is hard to date the structural breaks. The Chow test is not appropriate in this situation because it requires knowing in advance when the breaks did occur.

Table 2. Estimation of the univariate time series model

\begin{tabular}{lcc}
\hline & $\begin{array}{c}\text { Per-capita GDP } \\
\mathbf{1 8 1 0 - 2 0 0 9}\end{array}$ & $\begin{array}{c}\text { Per-worker GDP } \\
\mathbf{1 8 3 3 - 2 0 0 9}\end{array}$ \\
\hline$\phi_{1}$ & 0.002 & 0.002 \\
& $(0.001)$ & $(0.001)$ \\
$\phi_{2}$ & 0.998 & 0.997 \\
& $(0.071)$ & $(0.076)$ \\
$\phi_{3}$ & -0.113 & -0.136 \\
& $(0.072)$ & $(0.076)$ \\
$\phi_{0}$ & 0.575 & 0.831 \\
\hline$\phi_{1} /\left(1-\phi_{2}-\phi_{3}\right)$ & $(0.165)$ & $(0.217)$ \\
\hline$R^{2}$ & 0.016 & 0.016 \\
$\mathrm{DW}$ & $(0.001)$ & $(0.001)$ \\
$Q(p$-value $)$ & 0.995 & 0.997 \\
$Q^{2}(p$-value $)$ & 1.981 & 1.992 \\
$\mathrm{JB}$ & 0.470 & 0.471 \\
\hline
\end{tabular}

Notes: DW $=$ Durbin-Watson statistic. $Q=$ Minimum $p$-value of the Ljung-Box test for white noise in the residuals. $Q^{2}=$ Minimum $p$-value of the Ljung-Box test for white noise in the squared residuals. $\mathrm{JB}=p$-value of the Jarque-Bera normality test. Standard errors in parenthesis.

Bai and Perron $(1998,2001)$ derive several tests for multiple structural breaks in linear models, such that the date of the break is not imposed by the researcher but is endogenously determined by the data. Table 3 shows the result of the Bai-Perron test for each equation presented in Table 2. The UDmax test rejects the null hypothesis of no break 
against the alternative of an unknown number of breaks, while $\operatorname{SupF}_{t}(1)$ rejects the null in favor of the alternative of one break. Bai and Perron also developed a sequential break test to determine the number of breaks. $\operatorname{SupF}(j+1=j)$ tests the null hypothesis of $j$ breaks against the alternative of $j+1$ breaks. For both variables, per-capita and perworker GDP, the $\operatorname{SupF}(2 / 1)$ test cannot reject the null of two breaks, but $\operatorname{SupF}(3 / 2)$ rejects the null of three breaks. The bottom row shows the most likely dates of the breaks. For both equations, there is clearly a break in 1929, the year the Great Depression began. Surprisingly, the second break shows a 10-year difference between the two models: 1971 for per-capita GDP and 1981 for per-worker GDP. We do not have a plausible explanation for this difference, but there are two elements worth noting. First, there is a confidence interval for the date of the break, which is $[1969,1973]$ for the per-capita GDP series and [1979, 1983] for the per-worker GDP series. These intervals do not overlap, which suggests that the dates are statistically significant. Second, there was a large difference in the unemployment rate $(5.2 \%$ in 1971 and $15.5 \%$ in 1981), which could explain the significant difference between the dates of the breaks for these two series.

\section{Table 3. Bai-Perron test for structural breaks}

\begin{tabular}{|c|c|c|c|}
\hline \multicolumn{2}{|c|}{ Per-capita GDP } & \multicolumn{2}{|c|}{ Per-worker GDP } \\
\hline $\operatorname{SupF}_{t}(1)$ & UDmax & $\operatorname{SupF}_{t}(1)$ & UDmax \\
\hline $26.80^{* *}$ & $34.16^{* *}$ & $33.07^{* *}$ & $40.96^{* *}$ \\
\hline $\operatorname{SupF}(2 / 1)$ & $\operatorname{SupF}(3 / 2)$ & $\operatorname{SupF}(2 / 1)$ & $\operatorname{SupF}(3 / 2)$ \\
\hline $36.03^{* *}$ & 8.25 & $40.72^{* *}$ & 5.5 \\
\hline Dates & 1929,1971 & Dates & 1929, 1981 \\
\hline
\end{tabular}

The next step is to estimate Equation (7) for each sub-period identified by the Bai-Perron test; the results are shown in Table 4 . Notably, the persistence parameters $\left(\phi_{2}\right.$ and $\left.\phi_{3}\right)$ and the instantaneous growth rate $\left(\phi_{1}\right)$ vary across different time periods. ${ }^{4}$ The bottom part of the

4. Recall that $\phi_{2}$ and $\phi_{3}$ are combinations of the capital share and the persistence of the shocks, but we cannot identify the value of each one separately. 
Table presents the implied long-term growth rate for each period. The first period shows the lowest growth rate of both per-capita GDP and per-worker GDP. The second period, which ends in a different year for each variable, exhibits a slightly higher growth rate than the first one. This analysis suggests that the shock associated with the Great Depression had a considerable impact on the level of per-capita GDP but a small effect on the growth rate. It is also notable that the instantaneous growth rate $\left(\phi_{1}\right)$ increased more during the second period compared to the first one (1.2\% compared to $0.5 \%)$, but the persistence, specifically $\phi_{3}$, changed in a way that reduced the longterm growth rate. In the last period (1972-2009 for per-capita GDP and 1982-2009 for per-worker GDP), Chile showed the fastest growth in its economic history. Per-capita GDP grew at 3.4\% while labor productivity increased by $2.7 \%$ per annum, which is remarkably high compared to any other time period. The next step is to look at the main events or processes in Chilean economic history to find plausible explanations for these structural changes.

Table 4A. Univariate time series model under each regime

\begin{tabular}{|c|c|c|c|c|c|c|}
\hline & \multicolumn{3}{|c|}{ Per-capita GDP } & \multicolumn{3}{|c|}{ Per-worker GDP } \\
\hline & $1810-1929$ & $1930-1971$ & 1972-2009 & $1810-1929$ & $1930-1981$ & 1982-2009 \\
\hline$\phi_{1}$ & $\begin{array}{c}0.005 \\
(0.001)\end{array}$ & $\begin{array}{c}0.012 \\
(0.002)\end{array}$ & $\begin{array}{c}0.008 \\
(0.002)\end{array}$ & $\begin{array}{c}0.007 \\
(0.002)\end{array}$ & $\begin{array}{c}0.010 \\
(0.002)\end{array}$ & $\begin{array}{c}0.005 \\
(0.003)\end{array}$ \\
\hline$\phi_{2}$ & $\begin{array}{c}0.709 \\
(0.092)\end{array}$ & $\begin{array}{c}0.703 \\
(0.130)\end{array}$ & $\begin{array}{c}1.090 \\
(0.144)\end{array}$ & $\begin{array}{c}0.692 \\
(0.097)\end{array}$ & $\begin{array}{c}0.753 \\
(0.121)\end{array}$ & $\begin{array}{c}1.394 \\
(0.277)\end{array}$ \\
\hline$\phi_{3}$ & $\begin{array}{l}-0.002 \\
(0.092)\end{array}$ & $\begin{array}{l}-0.358 \\
(0.117)\end{array}$ & $\begin{array}{l}-0.314 \\
(0.136)\end{array}$ & $\begin{array}{l}-0.083 \\
(0.097)\end{array}$ & $\begin{array}{l}-0.235 \\
(0.105)\end{array}$ & $\begin{array}{c}-0.582 \\
(0.248)\end{array}$ \\
\hline$\phi_{0}$ & $\begin{array}{c}1.435 \\
(0.305)\end{array}$ & $\begin{array}{c}2.895 \\
(0.504)\end{array}$ & $\begin{array}{c}0.359 \\
(0.188)\end{array}$ & $\begin{array}{c}2.436 \\
(0.514)\end{array}$ & $\begin{array}{c}2.781 \\
(0.454)\end{array}$ & $\begin{array}{c}0.856 \\
(0.489)\end{array}$ \\
\hline
\end{tabular}

Table 4B. Computations

\begin{tabular}{|c|c|c|c|c|c|c|}
\hline & \multicolumn{3}{|c|}{$\begin{array}{c}\text { Per-capita GDP } \\
1810-2009\end{array}$} & \multicolumn{3}{|c|}{$\begin{array}{c}\text { Per-worker GDP } \\
1833-2009\end{array}$} \\
\hline & $1810-1929$ & $1930-1971$ & 1972-2009 & $1810-1929$ & $1930-1981$ & $1982-2009$ \\
\hline$\phi_{1} /\left(1-\phi_{2}-\phi_{3}\right)$ & $1.77 \%$ & $1.86 \%$ & $3.43 \%$ & $1.91 \%$ & $2.05 \%$ & $2.71 \%$ \\
\hline
\end{tabular}




\section{DELVING DEEPER INTO THE BREAKS}

This section discusses historical episodes that could justify the structural breaks described in the previous section. There is an extensive body of literature that points to certain common factors such as trade regimes and government behavior to explain Chile's economic performance (Cariola and Sunkel, 1990; Meller, 1996; Lüders, 1998, and the references therein). Following these authors, we can define the episodes as a function of the orientation toward foreign trade and the government's role in the economy. In addition, the Chilean economy has been always dependent on natural resources, particularly minerals. Therefore, the relative price of these commodities may play an important role in shaping the country's economic performance. Table 5 summarizes the key features in these dimensions for the three periods defined in the previous section. The first period is 1833-1929, in which the growth rates of per-capita GDP and perworker GDP were 1.8 and $1.9 \%$, respectively. During this period the young republic began trading with new partners; prior to that, international trade had largely been limited to Spain. Chile's main exports were minerals (silver and copper before 1879, and nitrate after the War of the Pacific) and agricultural products (exported mainly to Australia and California in the mid-19th century). During the second period, after the Great Depression, the economy began a process of import substitution with an expanded state role in economic activity: government intervention peaked between 1971 and 1973. After 1974, the economy transitioned toward a free-trade model with limited state participation in economic activity, which Lüders (1998) refers to as a subsidiary role of the state.

Table 5. Features of Chilean economic history

\begin{tabular}{|lccc}
\hline Features & $\mathbf{1 8 3 3 - 1 9 2 9}$ & $\mathbf{1 9 3 0 - 1 9 8 1}$ & $\mathbf{1 9 8 2 - 2 0 0 9}$ \\
\hline NR- dependence & $\begin{array}{c}\text { Silver, Nitrate, } \\
\text { Copper }\end{array}$ & Copper & Copper \\
\hline X- orientation & $\begin{array}{c}\text { Trade with new } \\
\text { partners }\end{array}$ & $\begin{array}{c}\text { Forced import } \\
\text { substitution }\end{array}$ & $\begin{array}{c}\text { Outward } \\
\text { orientation }\end{array}$ \\
\hline G- role & $\begin{array}{c}\text { Republic's } \\
\text { consolidation }\end{array}$ & $\begin{array}{c}\text { Increasing } \\
\text { participation }\end{array}$ & $\begin{array}{c}\text { Subsidiary role } \\
\text { of the state }\end{array}$ \\
\hline Growth rate of per-capita GDP & $1.77 \%$ & $1.86 \%$ & $3.43 \%$ \\
Growth rate of per-worker GDP & $1.91 \%$ & $2.05 \%$ & $2.71 \%$ \\
\hline
\end{tabular}


It may be too simplistic to consider that only these features are relevant to understanding the growth process. However, the goal is to verify whether an examination of this element can explain structural changes in the evolution of per-capita GDP. Although there may be many significant historical episodes, here only those defined by the structural breaks are studied.

\subsection{First structural change: 1929}

The first break takes place in 1929. As mentioned by Lüders and Wagner (2003a), the Great Depression is viewed as a natural event that divided the economic history of the Western world. This is called the defining moment hypothesis.

There is little doubt that the Great Depression coincided with significant institutional and policy changes around the world, and particularly in Chile. However, that coincidence could be wrongly interpreted as causality. In the case of Chile, Lüders and Wagner (2003a) question this hypothesis on the grounds that the most important economic events took place before the Great Depression. For instance, the state's increasingly active role in the economy commenced in the 1920s with more market regulations and a higher tax burden. Before the Great Depression, Chile's terms of trade had begun collapsing with the invention of artificial nitrate, which replaced natural nitrate due to its lower price. By the early 1920s, nitrate prices were already low; the crisis merely deepened the drop in terms of trade. This event triggered the increasing protectionism observed in the 1930s, but does not explain the further increase in protectionism experienced by the country in the following decades.

Another important consequence (perhaps the most important) of the fall in exports was a decline in tax collection. According to evidence presented by Humud (1974), government expenditures were mainly financed by taxes on international trade (export and import taxes), revenue from state-owned firms and to a lesser extent by internal taxes. Changes in taxes on international trade occurred along with the emergence of new interest groups, which in the early days of the republic sought monopoly power in certain activities. In addition, the mercantilist view-popular at the time - led the government to impose relatively high import tariffs. As export activities became increasingly important, landowners and mine owners applied pressure for lower tariff protection. Thus, while prior to 1885 import tariffs 
had been more important than export taxes, after that time export taxes became the main source of customs revenues (Humud, 1974).

Chile became particularly dependent on export taxes after the War of the Pacific, which resulted in Chile taking control of the nitraterich Tarapacá and Antofagasta regions. The domestic tax burden was relatively low, as the government financed its budget with export taxes (Díaz et al., 2003; Lüders and Wagner, 2003b). This may have been optimal from the point of view of the Chilean economy, given the country's monopoly power in the international nitrate market. When export tax collection started decreasing, it was rapidly replaced by a direct domestic tax and (to a lesser extent) an indirect domestic tax. As mentioned earlier, income tax was not a source of government revenue; in fact, during the 19th century Chile had no permanent income tax law and it wasn't until 1924 that one was enacted (Law 3,996). As described by Humud (1974), this law abolished specific taxes and imposed new taxes on real estate (9 percent), capital gains (4.5 percent), industrial and commercial profits (3.5 percent), mining profits (5 percent) and wages and salaries ( 2 percent).

This change in the structure of the fiscal budget had a significant impact on the economy, since the government replaced an "optimal tax" (although it is difficult to determine whether it was set at the optimal rate; see Lüders and Wagner, 2003c) with a distortionary tax scheme. Table 6 illustrates how revenues collected from different sources changed over time. The simple model presented in Section 3 could be modified to introduce a government that makes transfers to the private sector that are financed by transfers from abroad via the tax on nitrate exports, so the resource constraint given by (2) will be modified accordingly. Transfers from abroad abruptly stopped due to a negative terms-of-trade shock and the substitution of natural nitrate with artificial nitrate. Therefore, in order to finance transfers to the private sector, the government levied income taxes, reducing the marginal productivity of capital. In a model like this, the new tax structure will have a permanent effect on the level of per-capita and per-worker GDP. This policy, combined with the change in trade strategy, could explain why per-capita GDP did not return to the original trend as shown in Panel (b) of Figure 1. Another plausible explanation is that the transitory shock of the Great Depression had a permanent effect on the level of per-capita GDP, which is consistent with the idea of endogenous growth and unit root in the per-capita GDP series. This idea was ruled out by the evidence presented in Section 2, which rejected the unit root 
hypothesis against the alternative of stationarity and structural breaks (Zivot and Andrews test). Considering the permanent changes in the structure of the taxation scheme and the outward-oriented strategy, it is more likely that the economy experienced a permanent impact in the level of per-capita GDP, since the growth rate after the break is similar to the one in the previous period.

Table 6. Different sources of taxation

\begin{tabular}{|c|c|c|c|c|}
\hline Period & $\begin{array}{c}\text { Taxes on } \\
\text { mineral resources }\end{array}$ & $\begin{array}{c}\text { Direct } \\
\text { taxes }\end{array}$ & $\begin{array}{c}\text { Indirect } \\
\text { taxes }\end{array}$ & $\begin{array}{l}\text { Other } \\
\text { revenues }\end{array}$ \\
\hline $1900-1914$ & 50.5 & 0.01 & 35.2 & 14.3 \\
\hline $1915-1920$ & 48.3 & 5.8 & 34.2 & 11.1 \\
\hline $1921-1925$ & 24.3 & 5.3 & 28.1 & 42.3 \\
\hline 1926-1931 & 25.3 & 16.3 & 39.6 & 18.9 \\
\hline 1932-1939 & 11.9 & 15.3 & 44.7 & 28.0 \\
\hline $1940-1945$ & 17.1 & 16.2 & 35.2 & 31.5 \\
\hline $1946-1950$ & 19.8 & 22.7 & 38.9 & 18.6 \\
\hline
\end{tabular}

\subsection{Second structural change: 1971 or 1981}

The second structural break took place in the years 1969-1973 for percapita GDP and 1979-1983 for per-worker GDP. As described later in this paper, between 1973 and 1981 drastic structural reforms were implemented. In order to understand this second break, an overview of the economic policies of the Chilean government between 1940 and 1973 is necessary. The most important changes in economic policy during 1940-1973, compared to the previous period, are related to trade and government intervention (see Meller, 1996).

After the Great Depression, the state expanded its participation in economic activity and implemented a new development strategy. Like many other countries, Chile embarked on a push for industrialization based on an import substitution strategy. ${ }^{5}$ The objectives of this strategy were to isolate the economy from external volatility and grow its industrial base. In the period from 1930 to 1973 , increasing trade protections were

5. Meller (1996) argues that Chile began following this inward-focused strategy in the 1930s, well before ECLAC recommended this policy in the 1950s. 
put in place to support the country's nascent industries. Among other mechanisms, the Chilean government introduced exchange rate controls, high import tariffs on a large variety of goods, quotas, advance deposit requirements for imports, bans on certain imports, and implicit and explicit subsidies. As expected, the structure of protective measures did not follow a specific strategy, but resulted from the relative power of different interest groups lobbying for higher protection. Although the share of manufacturing industry output in total GDP increased from 11 percent in 1925 to 25 percent in 1973, the industry was highly inefficient and incapable of surviving without barriers to trade.

Figure 2 shows that Chile's outwardly oriented strategy after independence increased trade (exports plus imports as a percentage of GDP) and that after the steep decline in international trade at the time of the Great Depression, the openness of the economy essentially experienced no change until 1974. An upward trend was observed during the last period of analysis, interrupted only by a couple of years during the financial crisis of 1982. This trend was mainly explained by an aggressive outwardly oriented strategy after 1973 (we will revisit this point later).

\section{Figure 2. External openness}

(Exports plus imports over GDP)

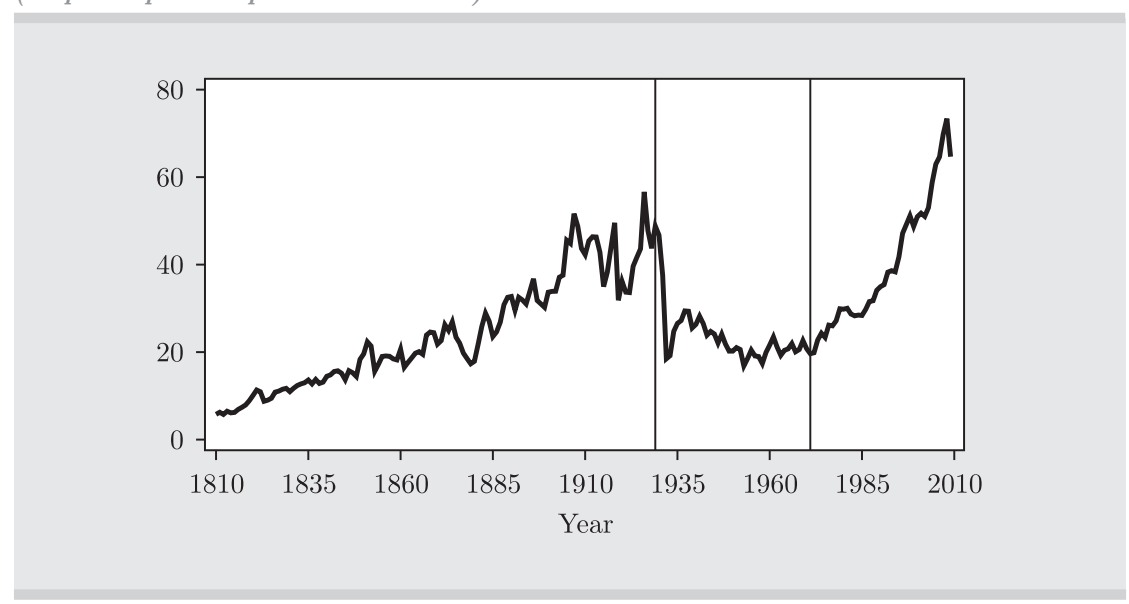

Source: Díaz et al. (2003).

Another area in which there were important changes during this period was the role of the state in the economy. Between 1940 and 1970, the 
state transitioned from promoting private investment through credit to the private sector to an entrepreneur state with large state-owned enterprises, and finally to a social planning state managing economic activity through taxes, subsidies and credit (Meller, 1996). The Allende government elected in 1970 deepened this central planning role, nationalizing the largest copper mines and taking control of numerous private firms in the industrial and banking sectors. By 1972, the contribution of stateowned enterprises to GDP reached 39\%, compared to $14 \%$ in 1965 . This experiment ended suddenly in 1973 with the military coup. Although the leaders of the new military government believed the system as it had evolved was not working, initially they did not have a specific program in mind. After seeking advice from a group of U.S.-trained economists, the government began a major reform with the overarching goal of moving from a state that was highly involved in economic activity to a market-oriented system. ${ }^{6}$ The main reforms applied were: ${ }^{7}$

- Price liberalization, including the interest rate. Before 1973, the government set the prices of most goods and services in the economy, including interest and exchange rates (multiple exchange rates existed at that time).

- The state's heavy involvement in economic activity came to an end. This occurred in several ways. On the one hand there was a change in fiscal policy, with fiscal responsibility becoming one of the cornerstones of the success of Chile's economy in subsequent years. The government abruptly reduced the fiscal deficit. On the other hand, a massive privatization process was carried out during the late 1970s and 1980s.

- $\quad$ Trade and finance liberalization. Import tariffs were cut drastically and non-tariff barriers were eliminated. The private sector was given access to the international market and a new law was enacted to attract foreign direct investment.

- Reforms in other areas: changes in the Labor Code, reduction of union power, replacement of the pay-as-you-go pension system with a private system, etc.

Once again, the two most significant reforms were related to the state's role in the economy and the trade regime (Chumacero et al., 2007).

6. See Aninat et al. (2004) and Chumacero et al. (2007) for an analysis of the political economy of the reforms.

7. An exhaustive analysis of the reforms can be found in the book edited by Larraín and Vergara (2000). 
When the country returned to democratic rule in 1990, the succeeding governments deepened the external orientation of the economy through unilateral tariff reductions and free trade agreements with numerous partners. The effect of these policies can be seen in Figure 2, which shows an upward trend in the measure of openness. The governments since 1990 have adhered to a policy of fiscal responsibility, which has become one of the central pillars of Chile's economic success by providing macroeconomic stability. As seen in Figure 1, Panel (b), all of this caused an acceleration in the growth process and allowed the economy to coincide with the long-run trend by 2008. According to the theoretical model presented here, the economy should move to a new long-run equilibrium with a higher per-capita income level. The question is whether this income level will be the one given by the long-term trend or higher.

\section{AN EXTENDED EMPIRICAL MODEL}

Considering that government involvement and trade orientation played an important role in explaining the episodes defined by the structural changes found in previous sections, it seems necessary to modify the univariate model to take that into account. Chumacero and Fuentes (2006b) estimate a similar model (for 1960-2000) for a group of seven Latin American economies (Argentina, Brazil, Chile, Colombia, Paraguay, Peru and Uruguay), finding no evidence of structural breaks in per-capita GDP after controlling for terms of trade and government expenditures over GDP. The one exception was Paraguay, which experienced a structural change in 1981. The countries in the sample had different growth experiences, but their structure has been stable when including these variables.

More specific to Chile, Chumacero and Fuentes (2006a) develop a two-sector neoclassical model that allows for a natural-resource sector, which is an endowment, and a productive sector that uses capital and labor. In this scenario there is a government that levies taxes on the private sector. Government expenditures are composed of lump-sum transfers to the private sector plus another portion that is not valued by society. These two features allow them to include terms of trade and government expenditures in the empirical model.

A measure of trade openness and government expenditure must be added to the empirical model. Based on the literature, it seems 
important to include terms of trade to control for a proxy of external conditions. This variable seems to be important in explaining the structural breaks in the 1960-2000 period (Chumacero and Fuentes, $2006 \mathrm{~b})$. The inclusion of these variables is justified in the theoretical literature, as control for the steady state equilibrium, but the literature is silent about the structure of the lags to be employed. Here we use the idea of estimating a general model, which is progressively simplified to a more parsimonious structure (general to particular, Hendry, 1985). The equation to be estimated is:

$$
A(L) \ln y_{t}=a_{0}+a_{1} t+B(L) g_{t}+C(L) \tau_{t}+D(L) T_{t}
$$

where $g$ represents the ratio of government expenditures to GDP, $\tau$ is the average import tariff and $T$ stands for the log of terms of trade. ${ }^{8}$ $A(L), B(L), C(L)$ and $D(L)$ are polynomial in the lag operator. Two lags of each variable are included in the estimation of Equation (8).

\section{Table 7. Univariate model conditioned by external conditions and government expenditures}

\begin{tabular}{lcc}
\hline 1833-2009 & Per-capita GDP & Per-worker GDP \\
\hline Trend $(t)$ & $0.003(0.001)$ & $0.003(0.001)$ \\
Per-capita GDP in $t-1(\log )$ & $0.812(0.045)$ & $0.957(0.117)$ \\
Per-capita GDP in $t-2(\log )$ & $-0.186(0.089)$ & $-0.144(0.72)$ \\
Average import tariff in $t-2$ & $-0.453(0.162)$ & $-0.272(0.208)$ \\
Government expenditure/GDP in $t-1$ & & $0.317(0.253)$ \\
Government expenditure/GDP in $t-2$ & $0.085(0.038)$ & $0.0361(0.015)$ \\
Terms of trade (logs) & $-0.090(0.048)$ & $1.103(0.312)$ \\
Terms of trade $(\operatorname{logs})$ in $t-2(\operatorname{logs})$ & $1.059(0.274)$ & $0.0154(0.001)$ \\
Constant & $0.0156(0.001)$ & 0.905 \\
Long-run growth rate & 0.166 & 0.000 \\
$Q(p$-value) & 0.000 & 0.000 \\
$Q^{2}(p$-value $)$ & 0.000 & \\
JB & & \\
\hline Note: Standard errors in parenthesis. & & \\
\hline
\end{tabular}

8. Government expenditures are proxied by government expenditures in the national accounts. Before 1940, the series was extended using real government expenditures from the fiscal accounts in Díaz et al. (2003). The average import tariff is an estimation of total government revenues from import over the value of imports. 
The results of estimating Equation (8) are shown in Table 7. The coefficients for the trend and lags of per-capita and per-worker GDP are similar to those estimated in Section 4, yielding almost the same long-run growth rates as those estimated in Table 2. The negative coefficient for the government-expenditures-to-GDP ratio indicates that an increase in this variable reduces the level of per-capita GDP, but it does not have a statistically significant effect on per-worker GDP. Trade distortions, measured as the implicit import tariff, have a negative impact on both per-worker and per-capita GDP. The terms of trade have a positive and then a negative effect on per-capita GDP, but, as expected, they have no effect in the long run; in the case of per-worker GDP, this effect is positive and statistically different from zero. Beyond the value of the coefficients, what is important in this analysis is whether the inclusion of these variables could eliminate the structural breaks in the growth process of the Chilean economy.

The battery of Bai-Perron tests applied to the univariate model are applied again to the extended model and show no evidence of a break whatsoever. Therefore, fiscal policy and openness to international trade explain the structural breaks found in the analysis of 200 years of Chile's economic growth.

\section{Concluding Remarks}

The economic history literature divides Chilean economic history into several episodes. This paper contributes to the discussion by providing a formal statistical analysis, based on a neoclassical growth model, to identify crucial moments in the country's economic history. These crucial moments have been associated with structural breaks in the neoclassical model.

A test to endogenously identify the breaks and thus avoid pretesting bias was used for the model, with per-capita GDP and per-worker GDP as dependent variables. The results of the test indicate that 1929 was the first break and 1971 and 1981 were the second breaks for per-capita GDP and per-worker GDP, respectively. The analysis of the three periods defined by these structural changes found that internal policies (specifically the role of government, fiscal policies and trade policies) and external shocks played a key role in the observed evolution of the variable of interest. Moreover, when trade 
openness, terms of trade and government expenditures over GDP are included in the empirical model, the evidence of structural breaks no longer appears.

Additional research should be conducted along these lines to explain the country's historical growth rate. There are at least two questions that deserve further research. First, why didn't per-capita GDP return to the level predicted by the original trend after the temporary shock of the Great Depression? The hypothesis posed here is that changes in the way government financed spending and changes in trade policies could explain this. In the former case, the government, due to an adverse external situation, switched its main source of financing from export taxes to domestic income taxes, which may have had a leveling effect in the context of the neoclassical growth model. Regarding trade policies, a more inwardly oriented strategy has a leveling effect on per-capita income, according to the theoretical model used here.

The second question is: Is this change in the growth trend simply a catching-up with the long-term trend or is it a transition to a new long-run equilibrium? By 2008, Chile's per-capita GDP reached its original trend. A more optimistic view could be that the Chilean economy is moving toward a new equilibrium. More time is needed to determine a final answer to this question. 


\section{REFERENCES}

Aninat, C., J. Londregan, P. Navia, and J. Vial (2004), "Political institutions, policymaking processes, and policy outcomes in Chile," mimeo, Universidad Adolfo Ibáñez, Santiago.

Bai, J. and P. Perron (1998), "Estimating and testing linear models with multiple structural changes," Econometrica 66(1): 47-78.

Bai, J. and P. Perron (2001), "Computation and analysis of multiple structural change models," Journal of Applied Econometrics 18: 1-22.

Cariola and O. Sunkel (1982), La historia económica de Chile: 1830-1930. Instituto de Cooperación Iberoamericana, Madrid.

Chumacero, R., J. R. Fuentes, R. Lüders, and J. Vial (2007), "Understanding Chilean reforms", in J.M. Fanelli (editor) Understanding Market Reforms in Latin America: similar Reforms, Diverse Constituencies, Varied Results, Palgrave-Macmillan, New York.

Chumacero, R. and J. R. Fuentes (2006a), "Chilean growth dynamics," Economic Modelling 23(2):197-214.

. (2006b). "Economic growth in Latin America: Structural breaks or fundamentals," Estudios de Economía 33(2):141-154.

Díaz, J.; R. Lüders, and G. Wagner (2003), "La república en cifras: 1810-2000." Manuscript Pontifcia Universidad Católica de Chile.

Humud, C. (1974), "Política económica chilena desde 1830 a 1930", Estudios de Economía 1(1): 1-122.

Jones, C. (1995), "Time series tests of endogenous growth models," Quarterly Journal of Economics 110: 495-525.

Kocherlakota, N.Y.K. Yi (1996), "A simple time series test of endogenous vs exogenous growth models," Review of Economic and Statistics 78: 126-34.

. (1996), "Is there endogenous long-run growth," Journal of Money, Credit and Banking 29: 235-62.

Lau, S. (1997), "Using stochastic growth models to understand unit roots and breaking trends," Journal of Economic Dynamics and Control 21:1645-67.

. (1999), "I(0) In, integration and cointegration out: Time series properties of endogenous growth models," Journal of Econometrics 93:1-24.

Lüders, R. (1998), "The comparative economic performance of Chile: 1810-1995," Estudios de Economía 25: 217-49.

Lüders, R. and G. Wagner (2003a), "The great depression: A defining moment in Chile's development?", Cuadernos de Economia-Latin American Journal of Economics 40(121):786-791.

. (2003b), "Early 1930ís: A unique period in fiscal evolution", Cuadernos de Economia-Latin American Journal of Economics 40(121):792-795. 
(2003b), "Nitrate export collapse and the Great Depression: Trigger or chance?", Cuadernos de Economia-Latin American Journal of Economics 40(121):796-802.

Meller, P. (1996), Un siglo de economía política chilena (1890-1990). Editorial Andrés Bello, Santiago de Chile.

Ng, S. and P. Perron (2001), "Lag length selection and the construction of unit root tests with good size and power," Econometrica 69: 1519-1554.

Zivot, E. and D. Andrews (1992), "Further evidence on the great crash, the oil-price shock, and the unit root hypothesis," Journal of Business and Economic Statistics 10: 251-70. 
